Securing the City 



\section{Securing the City}

Neoliberalism,

Space, and

Insecurity

in Postwar

Guatemala

Edited by

Kevin Lewis O'Neill

and

Kedron Thomas

Duke University Press

Durham and London

2011 
(ㄷ) 2011 Duke University Press

All rights reserved

Printed in the

United States of America

on acid-free paper @

Typeset in Quadraat

and Magma Compact

by Tseng Information Systems, Inc.

Library of Congress

Cataloging-in-Publication Data appear

on the last printed page of this book. 